\title{
Efektivitas dan Efisiensi Implementasi OVOP dalam Pengembangan IKM Gerabah di Kasongan
}

\author{
Aris Wahyudi \\ Program Pascasarjana Institut Seni Indonesia Yogyakarta \\ zyrajawa@gmail.com
}

\begin{abstract}
Abstrak
Penerapan One Village One Product (OVOP) di Indonesia mengadopsi OVOP di Jepang. Diinisiasi oleh Kementerian Perindustrian Republik Indonesia, OVOP merupakan pendekatan dalam mengembangkan Industri Kecil Menengah (IKM), khususnya IKM bidang kerajinan, dengan produk unggulan tertentu termasuk di Kasongan dengan produk unggulan gerabah. Dengan mengacu pada keberhasilan OVOP di Jepang, penerapan OVOP di Kasongan tidak bisa lepas dari prinsip dasar OVOP. Penerapan OVOP di Kasongan juga merupakan salah satu strategi pengembangan Klaster IKM Gerabah di Kasongan melalui peningkatan daya saing sehingga efektivitas dan efisiensi implementasinya harus dievaluasi. Penelitian ini bertujuan untuk menganalisis dan mengevaluasi implementasi program OVOP di Kasongan yang selanjutnya dihasilkan rekomendasi. Penelitian ini menggunakan pendekatan kualitatif yang menitikberatkan pada metode triangulasi dalam menganalisis data. Metode pengumpulan data primer dilakukan melalui wawancara semi terstruktur dengan narasumber baik dari unsur pengelola OVOP di Kasongan dan unsur IKM Gerabah di Kasongan peserta program. Data hasil wawancara direduksi ke dalam tabel dan kemudian dianalisis. Data sekunder berasal dari data dokumentasi dan studi pustaka. Dari analisis data ditemukan bahwa implementasi Program OVOP di Kasongan belum dilengkapi dengan buku petunjuk teknis OVOP dan sangat bergantung pada keberadaan seorang tokoh. Prinsip Local but Global, prinsip Self reliance and creativity, dan prinsip Human resource development yang seharusnya ada ternyata belum sepenuhnya dilakukan. Dengan kata lain, implementasi Program OVOP di Kasongan belum sesuai dengan prinsip dasar OVOP. Ketidaksesuaian ini menjadikan Program OVOP belum efektif dan efisien sebagai sebuah strategi pengembangan IKM sebagaimana yang diharapkan oleh Kementerian Perindustrian. Dalam hal ini, implementasi Program OVOP di Kasongan belum efektif dan efisien dari aspek pencapaian tujuan, integrasi, dan adaptasi.
\end{abstract}

Kata kunci: implementasi program ovop, pengembangan ikm gerabah kasongan, prinsip dasar ovop, efektif dan efisien

\footnotetext{
Abstract

The implementation of One Village One Product (OVOP) in Indonesia adopts OVOP in Japan. Initiated by Ministry of Industry of the Republic of Indonesia, OVOP is the approach in developing Small and Medium Industries, particularly in the field of handicraft with certain featured product, including Kasongan with pottery as its featured product. By referring to the success of OVOP in Japan, the implementation of OVOP in Kasongan cannot be separated from the basic principles of OVOP. The implementation of OVOP in Kasongan is one of development strategies for cluster of Small and Medium Industries in the field of Pottery in Kasongan through the improvement of competitiveness, so effectiveness and efficiency of its implementation must be evaluated. This research aims to analyze and evaluate the implementation of OVOP program in Kasongan which then results in the
} 
recommendation. This research used the qualitative approach which focuses on triangulation method in analyzing data. The method of primary data collection was implemented through a semi-structured interview with informants from the management of OVOP in Kasongan and Small and Medium Industries of Pottery in Kasongan as the participants of program. The data of interview were reduced into table and analyzed. The secondary data are from documentation and literature review. From the data analysis, it is found that the implementation of OVOP Program in Kasongan is not yet completed with the book of technical instruction of OVOP and it highly depends on the existence of a figure. The principles of Local but Global, Self-reliance and creativity, and Human resource development should exist, but they are not yet fully implemented. In other words, the implementation of OVOP program in Kasongan is not yet in accordance with the basic principles of OVOP. This inconsistency makes OVOP Program ineffective and inefficient as a development strategy of Small and Medium Industries as expected by Ministry of Industry. In this case, implementation of OVOP Program in Kasongan is not yet effective and efficient viewed from the aspects of goal achievement, integration, and adaptation.

Keywords: implementation of ovop program, development of small and medium industries of pottery in kasongan, basic principles of ovop, effective and efficient

\section{Pendahuluan}

Tidak dapat dipungkiri, Indonesia merupakan salah satu negara yang memiliki kekayaan budaya yang sangat beragam. Kekayaan budaya tersebut, salah satunya tercermin dari aneka ragam potensi produk kerajinan berbasis kekayaan budaya atau kearifan lokal yang memiliki nilai ekonomi. Produk kerajinan yang dimaksud yaitu produk kerajinan yang bersumber dari nilai-nilai dan pemanfaatan potensi setempat, baik potensi sumber daya alam maupun sumber daya manusia. Selama ini produk-produk kerajinan tersebut lebih banyak berkutat di pasar lokal dan belum tergarap secara optimal, sehingga apabila dikelola dengan baik akan berpeluang untuk bersaing di pasar global yang selanjutnya dapat meningkatkan pendapatan dan membuka kesempatan kerja bidang ekonomi kreatif.

Produk kerajinan berbasis kearifan lokal di Indonesia lebih banyak dihasilkan oleh usaha berskala kecil menengah, lebih spesifik oleh Industri Kecil dan Menengah (IKM) bidang kerajinan. Di banyak negara di dunia, IKM dapat diandalkan sebagai penyangga perekonomian nasional. Tambunan (2002) menyatakan, pengembangan dan pertumbuhan IKM merupakan salah satu motor penggerak yang krusial bagi pembangunan ekonomi di banyak negara di dunia. Data dari Kementerian Negara Koperasi dan UKM menunjukkan bahwa sampai pada pertengahan tahun 2013, banyaknya IKM di Indonesia mencapai 99,99 persen dari jumlah seluruh unit usaha. Peranan IKM dalam penyerapan tenaga kerja juga sangat besar, yaitu menampung 99,44 persen dari seluruh angkatan kerja yang ada. Selain itu dari sisi pembentukan Produk Domestik Bruto (PDB), kontribusi IKM terhadap PDB mencapai 63,11 persen, sementara usaha besar yang merupakan 0,01 persen dari seluruh unit usaha memberikan andil sebesar 36,89 persen terhadap PDB.

Perkembangan IKM di Indonesia tidak lepas dari berbagai macam masalah. Tambunan (2002) mengungkapkan, ada beberapa masalah yang umum dihadapi oleh pengusaha kecil dan menengah seperti keterbatasan modal kerja dan/atau modal investasi, kesulitan mendapatkan bahan baku dengan kualitas yang baik dan harga terjangkau, keterbatasan 
teknologi, sumber daya manusia dengan kualitas yang baik (manajemen dan teknik produksi), informasi pasar, dan kesulitan dalam pemasaran.

Tingkat intensitas dan sifat dari masalah-masalah tersebut bisa berbeda tidak hanya menurut jenis produk atau pasar yang dilayani, tetapi juga berbeda antarlokasi/antarwilayah, antarsentra, antarsektor/antarsubsektor atau jenis kegiatan, dan antar unit usaha dalam kegiatan/sektor yang sama. Oleh karena itu, peran pemerintah dalam mengembangkan IKM bidang kerajinan sangat diperlukan.

Melalui Inpres Nomor 6 Tahun 2007 Tentang 'Kebijakan Percepatan Pengembangan Sektor Riil dan Pemberdayaan Usaha Mikro Kecil dan Menengah (UMKM)', pemerintah bertujuan mendorong efektivitas pengembangan IKM dengan pendekatan One Village One Product (OVOP). Lalu, Kementerian Perindustrian mencanangkan Program Pengembangan Industri Kecil Menengah (IKM) dengan diterbitkannya Peraturan Menteri Perindustrian Nomor 78/MIND/PER/9/2007 tentang Peningkatan Efektifitas Pengembangan IKM melalui One Village One Product (OVOP).

OVOP sendiri pada awalnya dirintis oleh Prof. Morihiko Hiramatsu yang saat itu menjabat sebagai Gubernur Oita, Jepang tepatnya pada tahun 1979. Diantara produk yang berhasil dikembangkan dengan pendekatan OVOP di Oita Prefecture adalah Jamur Shitake, Jeruk Kabasu, Green House Mikan, Beef, Aji, dan Barley (Shochu). Khusus untuk Jamur Shitake, penerapan Konsep OVOP telah memperlihatkan hasil gemilang. Dipta (2011) mengemukakan bahwa gerakan OVOP berhasil meningkatkan pendapatan petani setempat dengan kenaikan harga Jamur Shitake.

Oleh karena 'success story'-nya, OVOP kemudian diadopsi dan diduplikasi oleh negaranegara lain. Tercatat pada tahun 2007 sudah ada 51 negara yang mengadopsi OVOP. Diantaranya merupakan negara-negara berkembang seperti Malaysia, Filipina, Indonesia, Kamboja, Vietnam, Thailand, negara-negara di Asia Selatan, Afrika, Eropa Timur, dan Amerika Selatan. Penerapan Program OVOP di berbagai negara berkembang tersebut cenderung memperlihatkan hasil yang beragam. Di Thailand misalnya, meskipun terbilang berhasil seperti di Jepang, namun ditengarai masih dibayangi sejumlah ironi. Hal tersebut menurut Claymone (2011) tidak lepas dari pengaruh tiga faktor penting yaitu: konsentrasi pasar global, reliabilitas pemerintah, dan minimnya pengetahuan yang sesuai. Terlepas dari itu semua, Patrisina et al. (2011) menyatakan bahwa keberhasilan dan kekurangan pelaksanaan program OVOP, OTOP, dan sebagainya dapat dipelajari sebagai bahan yang sangat berharga untuk mengadaptasi atau menciptakan program sejenis di Indonesia.

Pendekatan OVOP di Indonesia salah satunya diterapkan untuk pengembangan IKM gerabah di Kasongan, Bantul, Daerah Istimewa Yogyakarta (DIY). Kasongan bahkan menjadi salah satu kawasan percontohan Program One Village One Product (OVOP) yang digadang oleh Kementerian Negara Koperasi dan UKM sejak tahun 2008. Tidak hanya itu, Kementerian Perindustrian melalui Direktorat Jendral Industri Kecil Menengah (IKM) menjadikan Sentra Kerajinan Gerabah Kasongan sebagai salah satu sentra binaan OVOP. Sejarah Kasongan memang pernah lepas dari aktivitas pembuatan kerajinan gerabah. Gustami (2014) mengemukakan, sebagai sebuah daerah, Kasongan mempunyai potensi sumber daya tangible dan intangible yang berakar pada proses pembelajaran kolektif, selain ditunjang sumber daya alam sekitar yang mendukung untuk usaha kerajinan gerabah. Produk kerajinan yang dihasilkan oleh perajin gerabah di Kasongan sangat beragam mulai dari guci, peralatan 
memasak, patung, dan kerajinan lainnya. Produk-produk tersebut telah berhasil masuk dalam pasar internasional. Sebagian besar produknya sudah diekspor ke Amerika, Eropa dan Australia.

Dalam kasus penerapan OVOP di Kasongan, evaluasi implementasi program OVOP di Kasongan penting dilakukan. Hal ini menyangkut efektivitas dan efisiensi pendekatan OVOP sebagai sebuah strategi. Namun yang patut diperhatikan, pendekatan OVOP hanyalah satu strategi pengembangan IKM Gerabah di Kasongan. Dengan mengingat kompleksnya permasalahan IKM pada umumnya, seperti keterbatasan modal kerja dan/atau modal investasi, kesulitan mendapatkan bahan baku dengan kualitas yang baik dan harga terjangkau, keterbatasan teknologi, sumber daya manusia dengan kualitas yang baik (manajemen dan teknik produksi), informasi pasar, dan kesulitan dalam pemasaran, pendekatan OVOP tidak bisa dilihat sebagai pendekatan yang holistik. Dengan pertimbangan tersebut, pada akhirnya membuat penelitian ini memiliki keterbatasannya.

\section{Tinjauan Pustaka}

\section{Efektivitas dan Efisiensi}

Peter Drucker (dalam Stoner, 1994: 9) menyebutkan bahwa efektivitas adalah melakukan pekerjaan yang tepat. Sastradipoera (1989: 126) mengatakan, efektivitas adalah sesuatu yang menunjukkan tingkatan keberhasilan kegiatan manajemen di dalam mencapai tujuan yang telah ditetapkan sebelumnya. Emerson dalam Handayaningrat (1985) yang menyatakan bahwa efektivitas adalah pengukuran dalam arti tercapainya tujuan yang telah ditentukan sebelumnya. Mahmudi (2005) menjabarkan efektivitas dengan lebih rinci lagi, yaitu merupakan hubungan antara output dengan tujuan, semakin besar kontribusi (sumbangan) output terhadap pencapaian tujuan, maka semakin efektif organisasi, program atau kegiatan.

Efisien, menurut Drucker dalam Stoner (1994: 9), mengacu pada melakukan sesuatu itu dengan benar. Tersebab penelitian ini bersifat kualitatif, efisiensi dipandang sebagai pengaruh-pengaruh yang ada dibandingkan dengan bagaimana implementasi OVOP di Kasongan. Dengan mengacu pada pendapat Drucker, implementasi yang sesuai dengan perencanaan akan berimbas pada efisiensi OVOP untuk pengembangan IKM gerabah di Kasongan.

Terdapat 12 prinsip efisiensi menurut Harrington Emerson (1853-1931) yaitu: tujuan dirumuskan dengan jelas, kegiatan yang masuk akal, adanya staf yang cakap, disiplin, balas jasa yang adil, laporan yang terpercaya, pemberian perintah perencanaan dan pengaruh kerja, adanya standard dan jadwal kegiatan, kondisi yang distandarisasi, operasi yang distandarisasi, adanya instruksi tertulis yang standar, penghargaan efisiensi.

Menurut Duncan dalam Steers (1985: 53), ukuran efektivitas mencakup pencapaian tujuan, integrasi, dan adaptasi. Ketiga faktor tersebut apabila dijabarkan akan didapatkan tujuh faktor turunan (subfaktor) yang dapat dijadikan sebagai indikator untuk menilai efektivitas. Penjabaran ketiga faktor adalah sebagai berikut: 
a. Pencapaian tujuan; adalah keseluruhan upaya pencapaian tujuan harus dipandang sebagai suatu proses. Oleh karena itu, agar pencapaian tujuan akhir semakin terjamin, diperlukan pentahapan, baik dalam arti pentahapan pencapaian bagian-bagiannya maupun pentahapan dalam arti periodisasinya. Menurut Duncan dalam Steers (1985: 53), pencapaian tujuan terdiri dari beberapa faktor, yaitu: (1) kurun waktu pencapaiannya ditentukan, (2) sasaran merupakan target yang kongktit, (3) dasar hukum.

b. Integrasi; yaitu pengukuran terhadap tingkat kemampuan suatu organisasi untuk mengadakan sosialisasi, pengembangan konsensus dan komunikasi dengan berbagai macam organisasi lainnya. Menurut Nazarudin dalam Claude (1994: 13), integrasi terdiri dari beberapa faktor, yaitu: (4) prosedur, (5) proses sosialisasi.

c. Adaptasi; adalah proses penyesuaian diri yang dilakukan untuk menyelaraskan suatu individu terhadap perubahan-perubahan yang terjadi di lingkungannya. Menurut Duncan dalam Steers (1985: 53) adaptasi terdiri dari beberapa faktor, yaitu: (6) peningkatan kemampuan, (7) sarana dan prasarana.

\section{One Village One Product (OVOP)}

One Village One Product (OVOP) pada awalnya dirintis oleh Morihiko Hiramatsu yang saat itu menjabat sebagai Gubernur Oita, Jepang tepatnya pada tahun 1979. Awalnya, OVOP adalah sebuah gerakan untuk membangun suatu wilayah berbasis produk unggulan. Prof. Morihiko Hiramatsu sebagai penggagas OVOP menyebutkan ada 3 prinsip utama OVOP, antara lain adalah:

- Local yet global; yakni bagaimana masyarakat dapat berpikir Global dengan bertindak lokal. Pada mulanya masyarakat mengembangkan produk khas/unik yang baik dengan kualitas unggul, kemasan baik, manfaat luar biasa yang tidak dapat digantikan dengan produk lain/product differential. Lambat laun produk tersebut dapat memiliki konsumen yang fanatik di dalam negeri yang selanjut berkembang ke pasar ekspor.

- Self-reliance and creativity; Pemerintah memberikan berbagai fasilitas hanya untuk pengembangan produk dengan program-program yang kompetitif yang terseleksi secara ketat. OVOP dimaksudkan bukan satu desa satu produk melainkan setiap desa memilih satu produk yang difasilitasi oleh pemerintah untuk dikembangkan. Program OVOP menghindari bantuan-bantuan yang akan mencederai semangat kemandirian, kreativitas dan inovasi masyarakat yang menghalangi keberhasilan program OVOP jangka panjang.

- Human resources development; bahwa pengembangan kapasitas Sumber Daya Manusia (SDM) harus senantiasa dilakukan untuk mengikuti perkembangan jaman; teknologi, produk, fashion, dan desain. 


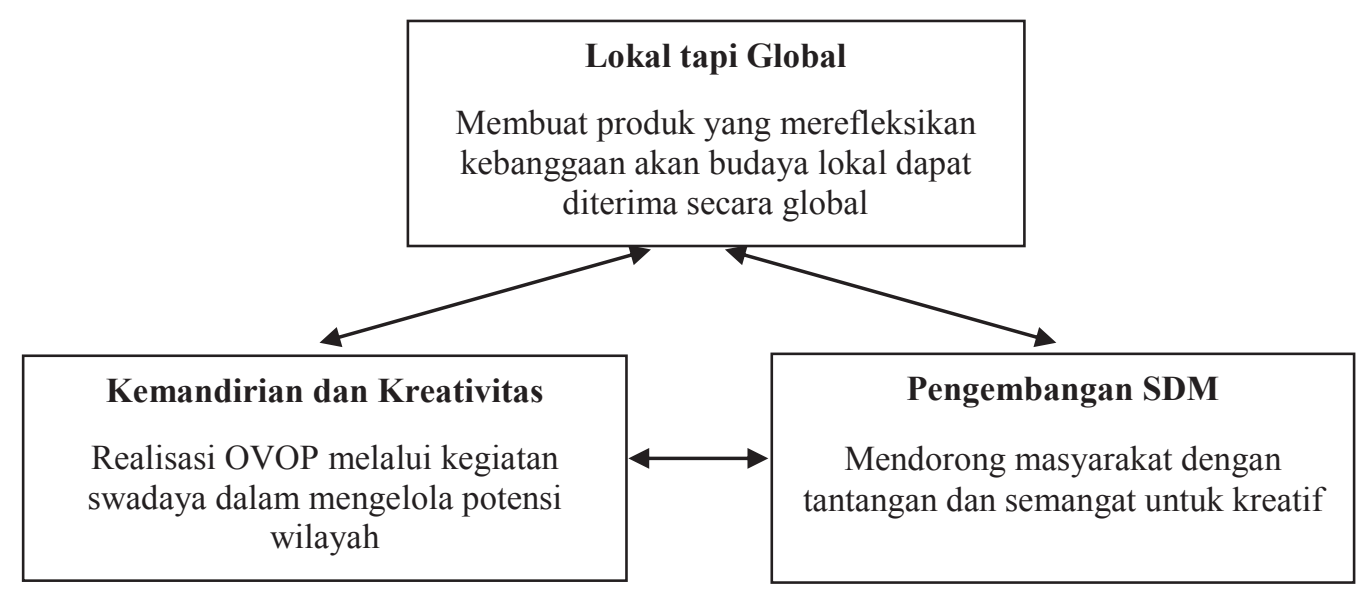

Gambar 1.

Prinsip Dasar One Village One Product (OVOP) menurut Morihiko Hiramatsu

Pada penerapan One Tombon One Product (OTOP), yaitu OVOP-nya Thailand, Jaiborisudhi (2009) menemukan bahwa masalah utama proyek OTOP adalah pada otoritas pemerintah yang lebih memegang kendali dan manajemen daripada masyarakat umum, yang mana memang menjadi karakteristik umum masyarakat Thailand. Sebagai akibat kurang dilibatkannya masyarakat dalam proyek OTOP di Thailand, Jaiborisudhi (2009) menjelaskan, hal ini telah membuat kurangnya kesadaran masyarakat setempat bahwa proyek ini milik semua orang. Dari temuan Jaiborisudhi tersebut, dapat diketahui bahwa secara umum kegagalan Program OVOP disebabkan kurangnya pemahaman masyarakat tentang program tersebut sehingga perlu dilakukannya pemberdayaan untuk meluruskan dan menjelaskan program OVOP agar dapat berjalan dengan baik.

Pada penelitian sebelumnya, dengan membandingkan penerapan OVOP di beberapa negara, Triharini (2014) mendapatkan faktor-faktor yang dapat digunakan sebagai parameter dalam menganalisis penerapan OVOP, yang disajikan dalam tabel berikut:

Tabel 1. Faktor-faktor yang menjadi parameter penerapan One Village OneProduct (OVOP)

\begin{tabular}{|c|c|c|c|}
\hline No. & Parameter Umum & \multicolumn{2}{|c|}{ Parameter Khusus } \\
\hline 1. & Tujuan & & \\
\hline 2. & Inisiator OVOP & $\begin{array}{l}\text { Pemerintah } \\
\text { Masyarakat } \\
\text { LSM }\end{array}$ & $\begin{array}{l}\text { Top-down } \\
\text { Bottom-up }\end{array}$ \\
\hline 3. & $\begin{array}{l}\text { Pihak yang terlibat selain } \\
\text { inisiator dan masyarakat }\end{array}$ & $\begin{array}{l}\text { Pemerintah } \\
\text { Sektor swasta } \\
\text { Universitas } \\
\text { Institusi lainnya }\end{array}$ & \\
\hline 4. & Sumber pendanaan & $\begin{array}{l}\text { Pemerintah } \\
\text { Masyarakat } \\
\text { LSM/LPSM } \\
\text { Lain-lain } \\
\end{array}$ & \\
\hline 5. & Tahap-tahap pelaksanaan & & \\
\hline
\end{tabular}




\begin{tabular}{|c|c|c|c|}
\hline 6. & $\begin{array}{l}\text { Bentuk partisipasi dalam } \\
\text { menentukan produk }\end{array}$ & $\begin{array}{l}\text { Pemerintah } \\
\text { Tim Ahli (konsultan, dll) } \\
\text { Masyarakat }\end{array}$ & \\
\hline \multirow[t]{6}{*}{7.} & \multirow[t]{5}{*}{ Desain } & Ide desain & $\begin{array}{l}\text { Perajin } \\
\text { Desainer }\end{array}$ \\
\hline & & Ciri-ciri desain & $\begin{array}{l}\text { Lokal } \\
\text { Trend }\end{array}$ \\
\hline & & Asal bahan/material & $\begin{array}{l}\text { Lokal } \\
\text { Dari luar daerah }\end{array}$ \\
\hline & & Teknik produksi & $\begin{array}{l}\text { Tradisional } \\
\text { Modern } \\
\text { Campuran }\end{array}$ \\
\hline & & Produk akhir & \\
\hline & Desainer & $\begin{array}{l}\text { Latar belakang keilmuan } \\
\text { Pengalaman mendesain }\end{array}$ & \\
\hline 8. & Bentuk pendampingan & $\begin{array}{l}\text { Pelatihan } \\
\text { Workshop } \\
\text { Seminar } \\
\text { Lain-lain }\end{array}$ & \\
\hline 9. & Jalur pemasaran (Promosi) & $\begin{array}{l}\text { Nasional } \\
\text { Internasional } \\
\text { Internet/Majalah/Pameran/la } \\
\text { in-lain }\end{array}$ & \\
\hline
\end{tabular}

Adapun penelitian ini akan menggunakan beberapa parameter penerapan OVOP seperti tampak dalam tabel, dengan pertimbangan bahwa parameter tersebut didasarkan pada analisis penerapan OVOP di berbagai negara yang mengadopsi OVOP dari Jepang, termasuk negaranegara di Kawasan ASEAN.

\section{Pengembangan Industri Kecil Menengah (IKM)}

Pengertian tentang IKM di Indonesia ternyata bervariasi. Setidaknya ada tiga lembaga yang menggunakan kriteria berbeda, antara lain Biro Pusat Statistik (BPS), Kementerian Perindustrian, dan Bank Indonesia. Secara umum, dalam pengertian IKM biasanya mencakup sedikitnya tiga aspek, yaitu aspek nilai investasi awal (jumlah aset), aspek omset, dan aspek jumlah tenaga kerja.

Dalam Peraturan Menteri Perindustrian Republik Indonesia Nomor 78/MIND/PER/9/2007 tentang Peningkatan Efektivitas Pengembangan Industri Kecil dan Menengah melalui Pendekatan Satu Desa Satu Produk (One Village One Product - OVOP) di Sentra, pengembangan IKM dengan pendekatan OVOP bertujuan untuk menggali dan mempromosikan produk inovatif dan kreatif lokal yang bersifat unik khas daerah serta meningkatkan daya saingnya.

Suryana (2001) mengatakan, strategi pengembangan IKM dapat didasarkan pada sumber daya internal yang dimiliki (resource-based strategy). Strategi ini memanfaatkan sumber daya lokal yang superior untuk menciptakan kemampuan inti dalam menciptakan nilai tambah (value added) untuk mencapai keunggulan komparatif dan keunggulan kompetitif. Akibatnya, perusahaan kecil tidak lagi tergantung pada kekuatan pasar seperti monopoli dan fasilitas pemerintah. Dalam strategi ini, IKM mengarah pada keterampilan khusus yang 
secara internal bisa menciptakan produk inti yang unggul untuk memperbesar pangsa manufaktur. Tambunan (2002) menandaskan, salah satu strategi pengembangan IKM yang sangat baik untuk diterapkan di negara-negara berkembang adalah pengelompokan (clustering). Kerja sama dan sekaligus persaingan antarsesama IKM di subsektor yang sama di dalam suatu kelompok (klaster) akan meningkatkan efisiensi bersama (collective efficiency) dalam proses produksi, spesialisasi yang fleksibel (flexible specialization), dan pertumbuhan yang tinggi.

Cahyani (2013), mengungkapkan bahwa pelaksanakan program OVOP di Indonesia sebagai salah satu upaya untuk memajukan potensi Usaha Mikro Kecil dan Menengah (UMKM) di daerah, difokuskan hanya pada perajin dan pengusaha pada suatu daerah. Huseini (2011) dalam Fitriani (2015) mengatakan bahwa daerah dikembangkan berdasarkan kompetensi intinya, bukan berdasarkan produk andalan ekspor yang selama ini dilakukan.

Berdasarkan penjabaran di atas, penulis menggarisbawahi bahwa OVOP di Indonesia diarahkan pada pengembangan IKM yang masih dihadapkan pada permasalahanpermasalahan dengan mengangkat produk unggulan sebagai pemacunya. Secara spesifik, OVOP juga berkaitan dengan pengembangan daya saing IKM, dengan asumsi bahwa IKM yang berdaya saing akan menghasilkan produk-produk berdaya saing pula. Maka, penerapan OVOP dalam pengembangan IKM sejatinya adalah pengembangan sumber daya manusia IKM.

\section{Metodologi}

Penelitian ini dilakukan di sentra industri kerajinan gerabah Kasongan. Penelitian dilakukan untuk mengetahui nilai variabel mandiri tanpa membuat perbandingan atau menghubungkan antara variabel yang satu dengan variabel yang lain. Penelitian ini merupakan penelitian evaluasi dengan pendekatan kualitatif. Bogdan dan Taylor (1975) dalam Moleong (2007: 3) mengemukakan bahwa metodologi kualitatif merupakan prosedur penelitian yang menghasilkan data deskriptif berupa kata-kata tertulis maupun lisan dari orang-orang dan perilaku yang diamati.

Sumber data primer diperoleh melalui wawancara dengan beberapa narasumber dari pengelola OVOP di Kasongan (Dinas Perindustrian Bantul, UPT Kasongan, dan Tokoh OVOP Kasongan) dan peserta Program OVOP (IKM gerabah di Kasongan). Penentuan narasumber bersifat purposive sampling, sehingga untuk menguji validitas data dilakukan dengan cara triangulasi sumber dan triangulasi metode. Selain itu, sumber data sekunder dari studi pustaka juga digunakan dalam penelitian ini. Informasi dari studi pustaka dapat berupa kajian dari penelitian sebelumnya. Selanjutnya studi pustaka juga akan digunakan dalam mendukung validitas dan keabsahan data.

Dalam menganalisis data, penulis menggunakan teknik analisis data interactive menurut Miles dan Huberman. Berikut ini adalah gambar model analisis data interaktif: 


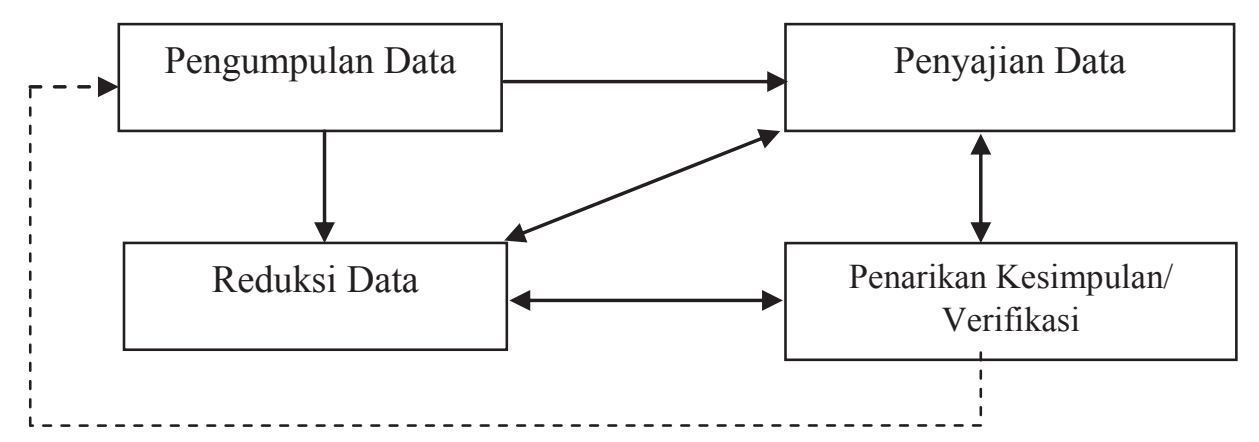

Gambar 2. Model analisis interaktif Miles \& Huberman

\section{Hasil dan Pembahasan}

\section{Latar Belakang OVOP di Kasongan}

Latar belakang program OVOP tidak terlepas dari potensi Kasongan sebagai penghasil kerajinan gerabah. Ada sekitar 582 pengrajin di Kasongan. Pada tahun 2008 sudah ada pencanangan Program OVOP di Kasongan. Namun ternyata tidak hanya Program OVOP yang dicanangkan di Kasongan, tetapi juga ada Program Cluster. Program OVOP dan Program Cluster muncul beriringan. Keberadaan dua program tersebut justru membingungkan. Akan tetapi sebenarnya dua program tersebut seiring sejalan dalam mengembangkan IKM gerabah di Kasongan. Hanya saja Cluster lebih bersifat bottom-up, sedangkan OVOP lebih bersifat top-down. Selain itu, OVOP di Kasongan juga tidak lepas dari rentetan program rehabilitasi pasca Gempa Bantul tahun 2006.

\section{Inisiator}

Program OVOP diinisiasi oleh Pemerintah Pusat, yaitu melalui kementerian yang dalam hal ini tidak hanya berjalan dari satu kementerian saja. Selain Kementerian Perindustrian, disebutkan ada Kementerian Pariwisata dan Kementerian Koperasi UMKM. Akan tetapi Kementerian Perindustrian yang paling mengambil peranan pada penerapan OVOP di Kasongan. Lagi pula, Kementerian Perindustrian yang masuk lebih dahulu di Kasongan dengan Program OVOP tersebut. Hal ini sesuai dengan apa yang dikatakan Triharini (2014). Menurutnya, penerapan OVOP di Indonesia dilaksanakan melalui program Kementerian Perindustrian sejak tahun 2008 untuk mengembangkan potensi IKM pada berbagai sektor, termasuk sektor kerajinan.

\section{Tujuan OVOP di Kasongan}

Tujuan Program OVOP di Kasongan difokuskan pada pengembangan produksi dan pengembangan pemasaran saja. Dalam hal pengembangan produksi, Program OVOP bertujuan mengembangkan kreativitas IKM dan meningkatkan produktivitas melalui pembinaan berkelanjutan. Sedangkan yang berkaitan dengan pengembangan pemasaran, tujuan Program OVOP di Kasongan adalah meningkatkan pasarnya agar bisa sampai ekspor ke seluruh dunia sehingga income dari berbagai perajin di Kasongan bisa berkembang. 


\section{Perencanaan Kegiatan}

Perencanaan kegiatan Program OVOP di Kasongan tidak hanya terbatas pada perencanaan di Pemerintah Pusat, namun juga melalui Focus Group Discussion (FGD) dan Musrenbang di Kasongan dengan melibatkan para pemangku kepentingan termasuk IKM Gerabah di Kasongan dan Pundong. FGD dan Musrenbang yang sudah dilakukan menghasilkan rencana aksi, berisi kegiatan-kegiatan yang akan dilaksanakan selama penerapan OVOP. Akan tetapi, adanya rencana aksi tidak mampu menjamin kegiatankegiatan akan terlaksana. Hal ini juga dipengaruhi oleh kurangnya komitmen berbagai pemangku kepentingan. Patut juga diketahui, dalam mengakomodir kebutuhan di Kasongan, Kementerian Perindustrian melakukan proses survey kepada IKM Gerabah di Kasongan. Survei tersebut untuk menampung kebutuhan-kebutuhan IKM yang dapat meliputi kebutuhan dana, kebutuhan pelatihan, kebutuhan peralatan, dan bantuan pemasaran.

\section{Pelatihan}

Pelatihan merupakan salah satu kegiatan utama Program OVOP di Kasongan. Pelatihan diselenggarakan dengan anggaran dari Kementerian Perindustrian. Rata-rata pelatihan berlangsung selama 10 (sepuluh) hari dan dengan jumlah peserta 20 (dua puluh) peserta tiap pelatihan, yang berasal dari IKM di Kasongan dan Pundong. Keikutsertaan IKM dari Pundong lebih pada kesamaan produk yang dihasilkan, yaitu gerabah. Pelatihan bertempat di UPT Kasongan, namun kadang juga diselenggarakan di hotel. Materi-materi yang diajarkan dalam pelatihan meliputi: materi tentang Desain, Teknik Produksi, Finishing, materi Pemasaran, materi tentang Manajemen, materi tentang Hak Atas Kekayaan Intelektual (HAKI), materi tentang Gugus Kendali Mutu (GKM), bahkan hingga materi tentang Kesehatan dan Keselamatan Kerja (K3). Sedangkan materi yang berkaitan dengan pemasaran melalui internet malah tidak ada menurut penuturan semua narasumber. Narasumber pelatihan dari unsur perguruan tinggi yang sesuai bidangnya.

\section{Fasilitasi Promosi dan Pemasaran}

Fasilitasi promosi dan pemasaran pada Program OVOP dilakukan dengan mengikutsertakan IKM peserta pelatihan pada pameran. Fasilitasi pameran oleh Kementerian Perindustrian dilakukan baik untuk skala nasional maupun internasional. Pameran yang pernah diikuti IKM gerabah Kasongan yaitu Pameran Produk Ekspor (PPE) dan juga TEI Expo. Pameran juga lebih sebagai ajang promosi daripada menjual produk gerabah. Setelah mengikuti pameran, ada IKM gerabah yang mendapatkan buyer dari luar negeri, meskipun tidak semua. Fasilitasi pameran dalam Program OVOP juga dirasa menguntungkan dari sisi pembiayaan. Dengan adanya fasilitasi dari Kementerian Perindustrian, biaya yang dikeluarkan untuk mengikuti pameran menjadi lebih ringan. Namun yang patut diketahui, bahwa sebelum penerapan OVOP di Kasongan, setiap perajin telah memiliki buyer mereka sendiri. Sehingga, dalam hal ini Program OVOP sebenarnya menyediakan peluang kepada perajin untuk menemukan buyer baru melalui keikutsertaan dalam pameran.

\section{Stakeholder dan Networking}

Penerapan OVOP dari Kementerian Perindustrian di Kasongan dilakukan melalui peran seorang penggerak OVOP, yaitu Bapak Timbul Raharjo. Penunjukkan ini terkait dengan 
ditetapkannya produk gerabahnya sebagai champion di Kasongan. Beliaulah yang mengkoordinasikan kegiatan OVOP di Kasongan dengan stakeholder yang lain. Peran beliau dapat juga disebut sebagai konsultan. Sebagai konsultan, Bpk. Timbul Raharjo diberi tugas untuk menyiapkan dan menyusun perencanaan untuk pelatihan teknis yang akan disampaikan atau diberikan kepada peserta pelatihan (perajin dan pelaku usaha kerajinan gerabah). Perencanaan pelatihan berdasarkan pada term of reference (TOR) atau Kerangka Acuan Kerja (KAK) yang sudah disusun oleh Kementerian Perindustrian. Selanjutnya, beliau juga bertanggung jawab untuk memformulasikan metode yang paling sesuai dalam pelatihan untuk perajin. Selain itu, sebagai konsultan beliau juga bertanggungjawab dalam menentukan target pelatihan, memberikan pelatihan dan juga memenuhi target pelatihan. Beliau menggandeng perguruan tinggi. Perguruan tinggi tersebut yaitu: Universitas Gajah Mada (UGM), Institut Seni Indonesia (ISI) Yogyakarta, Universitas Islam Indonesia (UII) Yogyakarta, dan Universitas Janabadra Yogyakarta.

Stakeholder yang lain yaitu Unit Pelaksana Teknis (UPT) Kasongan yang merupakan bagian dari Dinas Koperasi, Usaha Kecil Menengah, Perindustrian Kabupaten Bantul, dijadikan sebagai pusat informasi OVOP. Pelatihan-pelatihan OVOP berlangsung kebanyakan bertempat di UPT Kasongan. Dinas Koperasi, Usaha Kecil Menengah dan Perindustrian (pada waktu itu masih bernama Dinas Perindustrian, Perdagangan, dan Koperasi) juga memainkan peran penting. Pada saat implementasi Program OVOP di Kasongan, tidak semua staf dinas terlibat langsung di lapangan. Ada tim yang secara khusus terlibat langsung.

Selain yang sudah disebutkan, perusahaan Badan Usaha Milik Negara (BUMN) dan perbankan juga termasuk stakeholder pada Program OVOP di Kasongan. Peran mereka tidak bisa dianggap kecil dalam pengembangan IKM Gerabah di Kasongan selama berlangsungnya Program OVOP.

\section{Finansial}

Program OVOP sepenuhnya dibiayai oleh pemerintah pusat, yaitu dari anggaran Kementerian Perindustrian. Pembiayaan tersebut lebih banyak untuk pelatihan dan penyediaan fasilitas. Anggaran untuk pelatihan seratus persen dari pusat. Namun Pemerintah Kabupaten Bantul melalui Dinas Koperasi, Usaha Kecil Menengah, Perindustrian juga mengeluarkan anggaran dari Anggaran Pendapatan dan Belanja Negara (APBD) yang juga digunakan untuk pelatihan yang diharapkan dapat terintegrasi dengan anggaran Program OVOP dari Pemerintah Pusat.

Selain untuk dana operasional pelatihan, tidak ada pembiayaan lain, seperti misalnya pemberian bantuan modal. Hal ini diungkapkan, baik oleh narasumber pengelola maupun narasumber penerima manfaat program. Ketika IKM peserta OVOP mendapatkan pesanan untuk membuat produk tertentu, maka modal yang dibutuhkan untuk produksi ditanggung oleh mereka sendiri. Akan tetapi, pembiayaan usaha juga diupayakan melalui fasilitasi dengan mendatangkan institusi keuangan, baik CSR maupun Perbankan. Namun dengan adanya sarat dan ketentuan yang diberlakukan, fasilitasi tersebut tidak membawa hasil yang jelas. Misalnya, karena para peserta Program OVOP di Kasongan masih memiliki tanggungan pinjaman, maka bantuan permodalan pun urung disalurkan. 


\section{Program OVOP di Kasongan Ditinjau dari Prinsip Dasar OVOP}

Prinsip local yet global. Program OVOP di Kasongan menjadikan gerabah sebagai produk yang akan dikembangkan. Pemilihan ini berkaitan dengan latar belakang Program OVOP di Kasongan, dimana Pemerintah Pusat melalui Kementerian Perindustrian melihat potensi industri kerajinan di Kasongan untuk pasar ekspor ke luar negeri. Pada saat itu pasca gempa dan kondisi perekonomian dunia sedang bagus. Pemerintah melihat hal ini sebagai momentum yang tepat untuk menerapkan Program OVOP dimana program tersebut merupakan upaya pengembangan. Penentuan produk gerabah tentu sudah mencerminkan prinsip local yet global sebagaimana yang dicanangkan OVOP Jepang.

Prinsip self reliance and creativity lebih menekankan pada aspek kemandirian masyarakat dan bagaimana masyarakat turut serta dalam mengembangkan potensi mereka secara kreatif. Dalam pelaksanaan OVOP di Kasongan, pelaksana tidak menjalankan proses partisipasi masyarakat secara aktif dalam pengembangan OVOP. IKM Gerabah di Kasongan tidak mengambil peran lebih jauh selain sebagai peserta pelatihan. Itu pun juga tidak semua dilibatkan dalam pelatihan. Program OVOP di Kasongan juga lebih pada untuk memecahkan persoalan dari perajin di Kasongan daripada membangun kemandirian secara murni.

Human resource development mengarah pada bagaimana komunitas harus memiliki kemampuan yang cukup untuk bisa mengelola program OVOP, serta paham tentang substansi dari OVOP itu sendiri. OVOP di Kasongan sudah menjadikan komunitas sebagai pemilik dan pemelihara dari produk mereka sendiri. Akan tetapi IKM gerabah di Kasongan belum menjadi agen dalam mengembangkan produk, dan menjadikan OVOP sebagai sebuah kerangka pemikiran yang lebih luas. OVOP di kasongan sangat bergantung pada keberadaan seorang tokoh. Selain itu, adanya pelatihan ternyata belum memperlihatkan kontribusi dalam pengembangan SDM. Hal ini tidak terlepas dari sikap IKM Gerabah di Kasongan yang memegang prinsip hidup tertentu, misalnya prinsip dalam usaha asal tidak bangkrut. Sehingga harapan akan berkembangnya level usaha tampak masih jauh.

\section{Efektivitas dan Efisiensi Program OVOP dalam Pengembangan IKM Gerabah di Kasongan}

Berdasarkan analisis dan evaluasi atas atas implementasi Program OVOP di Kasongan pada bagian sebelumnya, efektivitas dan efisiensi Program OVOP ditinjau dari aspek pencapaian tujuan, integrasi, dan adaptasi dapat dijelaskan sebagai berikut:

- Aspek pencapaian tujuan. Implementasi Program OVOP belum optimal, yaitu dampak yang dihasilkan Program OVOP belum sesuai dengan perencanaan tujuan. Hal ini dapat disebabkan oleh kurangnya sinergi dan konsistensi baik dari inisiator maupun stakeholder yang terlibat program.

- Aspek integrasi. Oleh karena kurangnya partisipasi IKM Gerabah di Kasongan, efektivitas dan efisiensi implementasi Program OVOP di Kasongan juga belum optimal. Dengan hanya mengikutsertakan beberapa IKM Gerabah, baik dalam sosialisasi maupun pelatihan, Program OVOP belum mampu menggerakkan partisipasi IKM Gerabah di Kasongan pada umumnya.

- Aspek adaptasi. Berdasarkan implementasiny di Kasongan, Program OVOP belum efektif dan efisien. Hal ini dibuktikan dengan tidak ada perbedaan kemampuan IKM 
antara sebelum dan sesudah Program OVOP. Pun, tidak ada perbedaan sarana dan prasarana yang ada di Kasongan.

\section{Rekomendasi}

Berikut adalah rekomendasi atas evaluasi implementasi Program OVOP dalam pengembangan IKM Gerabah di Kasongan, baik untuk pemerintah maupun IKM:

a. Pemerintah

IKM Gerabah di Kasongan yang dilibatkan lebih diperluas lagi untuk memperkaya analisis kebutuhan yang sesuai dengan kebutuhan mereka. Tentu harus disertai dengan upaya memantapkan komitmen agar kegiatan yang diputuskan berdasarkan analisis kebutuhan tersebut dapat dilaksanakan bersama-sama ke depannya. Perlu ada sinergi lintas kementerian dalam pelaksanaan Program OVOP agar kegiatan di lapangan tidak tumpang tindih. Guna meningkatkan efektivitas dan efisiensi implementasi OVOP di Kasongan, pemerintah perlu mempertimbangkan untuk merelokasi bantuan teknis, yang sebelumnya masih dalam kendali pemerintah pusat ke pemerintah daerah, bahkan jika perlu langsung ke diserahkan sepenuhnya pada asosiasi/kelompok komunitas lokal OVOP. Adanya pelatihan sebagai salah satu kegiatan program juga harus disertai pengembangan kurikulum, yang menyangkut konsep dan cara pengajaran. Perlu perumusan kurikulum yang jelas dan berjenjang agar pelatihan lebih terarah. Dengan kurikulum yang jelas, maka materi pelatihan diharapkan mampu menjawab kebutuhan akan pengembangan sumber daya manusia IKM Gerabah di Kasongan. Dalam menentukan peserta harus lebih selektif lagi agar keikutsertaan IKM Gerabah di Kasongan tidak terkesan hanya memenuhi kuota yang ada. Perlu adanya assessment di awal sebelum mengikuti pelatihan. Pemerintah juga harus menjalin kerjasama yang lebih banyak lagi dengan dengan institusi pemerintahan yang lain dan pihak swasta guna memperluas jaringan pemasaran, sebab keberhasilan Program OVOP salah satunya ditentukan oleh terbukanya akses pasar yang seluas-luasnya. Monitoring dan evaluasi yang dilakukan oleh inisiator Program OVOP harus secara berkala dan konsisten. Peran UPT harus lebih dioptimalkan dengan meningkatkan kompetensi sumber daya manusia.

b. IKM Gerabah di Kasongan

IKM Gerabah didorong untuk melakukan pembatasan terhadap pembuatan produk gerabah yang didasarkan pada permintaan buyer dan diarahkan untuk lebih kreatif dalam memanfaatkan potensi yang dimiliki dalam mengembangkan produk. Memahami peran desain sebagai sebuah upaya untuk melestarikan nilai-nilai tradisional dari kerajinan sekaligus untuk memenuhi keinginan pasar. Lebih memanfaatkan komunitas-komunitas, baik koperasi maupun komunitas yang lain, yang telah terbentuk untuk dapat melaksanakan OVOP yang dapat melibatkan perajin-perajin di Kasongan secara meluas. Menggerakkan generasi muda untuk lebih aktif dalam kegiatan baik Program OVOP maupun program yang lain. Peningkatan keahlian atau keterampilan bagi generasi muda untuk mengantisipasi keberlanjutan usaha kerajinan di masa yang akan datang. 


\section{Kesimpulan}

Berdasarkan penelitian terdahulu, diperoleh hasil bahwa terdapat beberapa faktor penting dalam implementasi Program OVOP di Indonesia. Program OVOP di Indonesia bersifat topdown, hal ini membutuhkan upaya lebih untuk membuat OVOP dapat dipahami dan diterima sebagai spirit untuk membangun diri sendiri. Hal ini dapat dicapai dengan mencari tokoh sentral di dalam komunitas. Tokoh tersebut adalah orang yang mau mendengar dengan sungguh-sungguh, dan juga orang yang mau bekerjasama dengan pemerintah, dan mengerti pentingnya membangun komunitas di lingkungannya. Keberadaan tokoh tersebut akan membuat proses sosialisasi lebih efektif sehingga program akan diterima bukan hanya sebagai program pemerintah tetapi juga program untuk membangun diri mereka sendiri.

Berdasarkan penelitian yang penulis lakukan, Implementasi Program OVOP di Kasongan belum dilengkapi dengan buku petunjuk teknis OVOP dan sangat bergantung pada keberadaan seorang tokoh. Namun dalam implementasinya, prinsip local yet global, prinsip self reliance and creativity, dan prinsip human resource development yang seharusnya ada ternyata belum sepenuhnya dilakukan. Dengan kata lain, implementasi Program OVOP di Kasongan belum sesuai dengan prinsip dasar OVOP. Ketidaksesuaian ini menjadikan Program OVOP belum efektif dan efisien sebagai sebuah strategi pengembangan IKM sebagaimana yang diharapkan oleh Kementerian Perindustrian. Dalam hal ini, implementasi Program OVOP di Kasongan belum efektif dan efisien dari aspek pencapaian tujuan, integrasi, dan adaptasi.

\section{Kepustakaan}

\section{Buku:}

Gustami, SP. Dkk. 2014. Buku Kenangan Keramik Kasongan Heritage (Seni Kriya dan Kepariwisataan: Studi Kasus Pada Proses Kreatif dan Inovatif Seni Kriya Keramik Kasongan Yogyakarta). Jakarta: Direktorat Pengembangan Seni Rupa.

Handayaningrat, Suwarno. 1985. Pengantar Studi Ilmu Administrasi dan Managemen. Cetakan Keenam. Jakarta: PT Gunung Agung.

Mahmudi. 2005. Manajemen Kinerja Sektor Publik. Yogyakarta: Penerbit Buku UPP AMP YKPN.

Moleong, Lexy J. 2007. Metodologi Penelitian Kualitatif. Bandung: Penerbit Remaja Rosdakarya.

Steers, Richard M. 1985. Efektivitas Organisasi: Kaidah Perilaku, Seri Manajemen, No. 47. Jakarta: Penerbit Erlangga.

Stoner, J.A.F dan R.E. Freeman. 1994. Manajemen. Jilid 1. Edisi Kelima. Jakarta: Intermedia.

Suryana. 2000. Ekonomi Pembangunan: Problematika dan Pendekatan. Jakarta: Penerbit Salemba Empat.

Tambunan, Tulus T.H. 2002. Usaha Kecil dan Menengah di Indonesia: Beberapa Isu Penting. Jakarta: Penerbit Salemba Empat. 


\section{Jurnal:}

Cahyani, Rusnandari Retno. 2013. Pendekatan One Village One Product (OVOP) untuk Meningkatkan Kreativitas UMKM dan Kesejahteraan Masyarakat. Journal \& Proceeding FEB UNSOED, Vol 3, No 1 (2013).

Claymone, Yoopin \& Jaiborisudhi, Watunyu. 2011. A Study on One village One Product Project (OVOP) in Japan and Thailand as an Alternative of Community Development in Indonesia: A Perspective on Japan and Thailand. The International Journal of East Asian Studies, Vol. 16 No. 1, March-August 2011.

Jaiborisudhi, Watunyu. 2011. OVOP Network toward in East Asia and a Case study in Thailand: The authority between the government and the general public. The International Journal of East Asian Studies, Vol. 16 No. 1, March-August 2011.

Meirina Triharini, Dwinita Larasati \& R. Susanto. 2012. Pendekatan One Village One Product (OVOP) Untuk Mengembangkan Potensi Kerajinan Daerah Studi Kasus: Kerajinan Gerabah Di Kecamatan Plered, Kabupaten Purwakarta. Jurnal Visual Art \& Design, Vol. 6, No. 1. Bandung: Institut Teknologi Bandung (ITB). 